\title{
LONDON SCHOOL OF HYGIENE AND TROPICAL MEDICINE
}

\section{University of London}

The following postgraduate courses are offered:

Full and part-time $M S_{c}$ and diploma:

MSc Clinical Tropical Medicine

MSc Community Health in

Developing Countries

MSc Community Medicine

MSc Epidemiology

MSc Ergonomics

MSc Human Nutrition

Diploma in Epidemiology

Diploma in Human and

Clinical Genetics

Diploma in Industrial Health

Diploma in Medical Microbiology
MSc Medical Demography

MSc Medical Microbiology

MSc Medical Parasitology

MSc Medical Statistics

MSc Occupational Hygiene

MSc Occupational Medicine

Diploma of Professional Competence in Comprehensive Occupational Hygiene

Diploma in Tropical Medicine and Hygiene

Part-time courses not leading to an award are held in:

Medical Statistics and Epidemiology Population Studies

Research degrees:

MPhil and PhD

Further information may be obtained from:

The Registrar

London School of Hygiene and Tropical Medicine

Keppel Street

London WCIE 7HT, UK 